\title{
CAUSATION IN CANADIAN INSURANCE LAW
}

\author{
ERIK S. KNUTSEN*
}

Causation in insurance law is an area where courts continuously experience difficulties. This is largely because in insurance law causation is used as a payout trigger, a separate and distinct element from the traditional "but for" causation generally found in tort. This article proposes a framework for understanding the mechanics of causation as a payout trigger. This is done largely through a focus on the resulting loss and how it occurred. This framework also provides an opportunity to parse through the problems associated with concurrent causation (for example, when loss is caused by both smoke and fire after a lightning strike). Concurrent causation must be analyzed using a liberal approach derived from the Derksen case. The framework makes use of a temporal analysis to determine the relevance of a cause, working backward from the loss. In the final stages of the analysis, the language used in the insurance policy must be interpreted using a purposive approach by considering drafting intent, as well as the consequences of coverage and its associated gaps. The article aims to streamline insurance causation analysis in order to promote more consistent and holistic results in insurance coverage disputes.
La causalité dans le droit des assurances est un domaine qui donne du fil à retordre aux tribunaux, essentiellement parce que dans le droit des assurances, la causalité sert de déclencheur de dédommagement, soit un élément séparé et distinct de la causalité traditionnelle "en l'absence de » que l'on trouve habituellement dans le délit civil. Cet article propose un plan-cadre pour comprendre les mécanismes de la causalité en tant que déclencheur de dédommagement. L'examen se fait principalement partir de la perte qui en résulte et la manière dont celle-ci s'est produite. Ce cadre permet aussi d'analyser les problèmes associés à la causalité concomitante (par exemple, lorsque la perte découle à la fois de la fumée et d'un incendie après un foudroiement). La causalité concomitante doit être analysée au moyen d'une approche libérale dérivée de la cause Derksen.Le cadre fait appel à une analyse temporelle pour déterminer la pertinence d'une cause en faisant marche arrière depuis la perte en question. Aux dernières étapes de l'analyse, le langage utilisé dans la police d'assurance doit être interprété avec une approche fondée sur l'objet visé en envisageant de préparer une ébauche de l'intention ainsi que des conséquences de la protection et des écarts connexes. L'article vise à simplifier l'analyse de la causalité afin de promouvoir des résultats plus consistants et holistiques dans les conflits sur les garanties.

\section{TABLE OF CONTENTS}

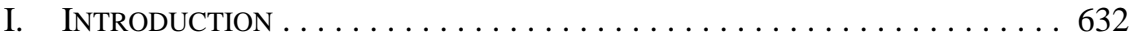

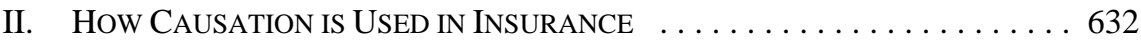

A. Types of InSURANCE CAUSATiOn Disputes . . . . . . . . . . . 634

B. Why Causation in InSURAnCE is ChaLLENGING . . . . . . . . 637

C. Insurance Causation is Not Tort Causation $\ldots . . \ldots \ldots 638$

III. Sifting Through THE CAUSAl MECHANICS AND

Finding the RELEVANT TARget CAUSE . . . . . . . . . . . . . . . 640

IV. CAusation in Automobile InSURANCE . . . . . . . . . . . . . . . . 644

V. Concurrent CAUSATION IN INSURANCE . . . . . . . . . . . . . . 646

A. What is Concurrent CaUsation in InSURANCE? . . . . . . . . . 646

B. Canada's Approach to Concurrent CaUsation . . . . . . . . 646

C. IdEnTifying THE Concurrent CAUSATION CASE . . . . . . . . . . 648

D. IndEMNITY FOR THE CONCURRENTLY CAUSED LOSS $\ldots \ldots \ldots \ldots 60$

E. Contracting Out of Concurrent Causation . . . . . . . . 653 
VI. Pleadings and Causation in InSURAnCE $\ldots \ldots \ldots \ldots \ldots \ldots \ldots$

VII. CONCLUSION .......................... 657

\section{INTRODUCTION}

Causation issues frequently dominate insurance coverage disputes. If a house is insured and damaged by both wind and flood, but the insurance policy covers only losses caused by wind and not flood, must the insurer indemnify the insured homeowner? What if the wind caused most of the damage to the house? If a daycare worker negligently fails to supervise some children while all are riding in the daycare's van on the way to a park, and one child is hurt by another child in the van, would the daycare's commercial general liability insurance policy provide her with coverage if she is sued by the injured child's parent? What if the policy excluded losses caused by automobile use? Or would her automobile liability insurance policy provide her with sufficient coverage instead? Is this a loss caused by automobile use?

When solving challenging insurance causation questions, it is important to understand the primary purpose behind any causal language at issue in an insurance policy. Causation is used to delineate payout triggers for the insurer by attempting to define finite instances of insured and uninsured losses. Causal language can be located in a coverage clause or an exclusion clause. The clause can broadly describe an occurrence, such as providing coverage for liability arising from "your actions anywhere in the world," or it can attempt to define the limits of a particular insured risk by describing the causal mechanics that must operate to bring about a loss, such as by excluding from liability insurance coverage those losses “caused intentionally” by an insured's conduct. Because it is often a very nuanced exercise to describe in an insurance policy precisely how insurance causation affects insurance coverage, courts have had much difficulty determining how insurance policies use causation to control insurance payouts. A coherent and predictable process for sorting through this causal inquiry would help to unify the jurisprudence and streamline the costly litigation around insurance causation issues.

This article provides a framework for solving both simple and complex insurance causation issues that recur in Canadian insurance law. It proposes a method for sifting through the causal mechanics of a loss and locating relevant target causes on which to focus the analysis. The article also proposes a process for disentangling disputes about losses resulting from concurrent causes. Central to the framework is the notion that decisions about insurance causation must follow a structured predictable and analytic process. Also central is the notion that causation in insurance necessarily operates in a fundamentally different manner than causation in tort — as a payout trigger, not a fault-based gate-keeper to compensation.

\section{How CAUSATION IS USED IN INSURANCE}

Causation in insurance law is used to signify when a payout is triggered under an insurance policy. It has a very different role than causation in tort law. Insurance policies are written to signify that the insurer only insures against losses brought about by fortuitous risks 
it has chosen to insure. ${ }^{1}$ In order to communicate this, the policy must attempt to define what, if any, is the insurer's liability to pay for a certain loss caused by a certain risk. The causal language used by insurers varies in form among particular insurance products and even from policy to policy; yet, regardless of the format, the causal language is simply meant to be a signification of payout conditions.

For example, standard homeowners and commercial insurance policies typically provide “all risks” property and liability insurance coverage. Broad spectrum liability insurance provides coverage for an insured's legal liability to pay damages for bodily injury or property losses arising out of the insured's actions anywhere in the world. ${ }^{2}$ Commercial and homeowners property insurance policies typically insure the property against "direct physical loss" to the property. ${ }^{3}$ These expansive insurance coverage provisions have meant that, in order to circumscribe the risks the insurer will not insure, the operative causal language in these policies has been relegated to exclusion clauses, not coverage clauses. ${ }^{4}$ The policies then use causal language to indicate that certain losses "caused by," "resulting from," or "arising out of” a certain risk are excluded from insurance coverage. ${ }^{5}$

Other types of insurance policies use causal language in slightly different fashions. Automobile liability insurance employs causal language in the coverage clause, agreeing to

See e.g. Erik S Knutsen, "Fortuity Clauses in Liability Insurance: Solving Coverage Dilemmas for Intentional and Criminal Conduct” (2011) 37:1 Queen’s LJ 73 at 75-78 [Knutsen, “Fortuity Clauses”]. Indeed, the concept of fortuity, which is key to insurance, is itself a causal concept, as only those losses beyond the insured's causal control are fortuitous and thus insurable. See Banks McDowell, "Causation in Contracts and Insurance” (1988) 20 Conn L Rev 569 at 589.

Such as the coverage clauses for the liability portion of a standard homeowners insurance policy or a commercial general liability insurance policy. Knutsen, "Fortuity Clauses," ibid at 76.

See e.g. Caneast Foods Ltd v Lombard General Insurance Co of Canada, 2008 ONCA 368, 91 OR (3d) 438 [Caneast Foods] (property coverage for “direct physical loss”); Goderich Elevators Ltd v Royal Insurance Co (1999), 42 OR (3d) 577 (CA) [Goderich Elevators] (property coverage for "direct physical loss").

4 There is some significance to this coverage-limiting causal language being located in exclusion clauses. Canadian law dictates that while coverage clauses are to be interpreted broadly, exclusion clauses are to be interpreted narrowly. An exclusion clause which attempts to use causal language to exclude coverage for a loss can thus receive a narrow interpretation by courts. This has the potential to restrict the impact of causal language in an all-risks insurance policy if the exclusion clause's meaning is at all ambiguous. See e.g. Derksen v 539938 Ontario Ltd, 2001 SCC 72, [2001] 3 SCR 398 [Derksen] (reviewing Canadian insurance policy interpretation principles, including the premise that coverage clauses are to be interpreted broadly and exclusion clauses narrowly). See also Goderich Elevators, ibid (coverage under an all risks property policy for grain damaged by heating was permitted because causal language was located in the exclusion clause and was thus interpreted narrowly).

5 To make matters worse, many courts make fine and imperceptible distinctions between the different phraseology of the causal language used in insurance policies, often imbuing an insurer's particular choice of language with some drafting intent for which there is no evidence to prove. It is doubtful insurers meant to put such a fine cut on the language. The phraseology probably arises from path dependence on standard form language rather than any insurer intent to have the words mean something special. Few insureds could predict the differences between the phraseology because the nuances are not explained in the policy language. It is far better for courts to simply hold that causal language in all its forms is causal language that simply means the loss requires some palpable causal connection. See e.g. TR Construction Ltd v Wawanesa Mutual Ins Co, 2008 MBQB 182, [2008] 12 WWR 302 [TR Construction] ("arising out of" in an automobile policy requires a loose causal connection traceable in a continuous chain); Amos v Insurance Corp of British Columbia, [1995] 3 SCR 405 at para 26 [Amos] ("arising out of" in automobile policy language broader than "caused by" language); Hanlon $v$ ING Insurance Co of Canada, 2011 BCSC 73, 16 BCLR (5th) 390 (no reason to ascribe any meaning to "direct" in a coverage clause insuring for "direct damage" "caused by" vandalism; "caused” should be read as unmodified); Minox Equities Ltd v Sovereign General Insurance Co, 2010 MBCA 63, 321 DLR (4th) 173 [Minox] ("directly or indirectly" means that both direct and consequential loss of an event are captured; concurrent causes are excluded by this wording). See also Gordon Hilliker, Liability Insurance Law in Canada, 4th ed (Markham: LexisNexis, 2006) at 85 ("arising out of" does not mean the same as “directly caused by"). 
pay for legal liability “arising out of” or "resulting from” the "ownership, use or operation of an ... automobile.”6 Accidental death and dismemberment policies ${ }^{7}$ incorporate causal concepts into the coverage clause. Payout is triggered as long as death or injury is "resulting from" or "occasioned through" an "accident” or by "accidental means." ${ }^{8}$ Disability insurance policies and health insurance policies may also incorporate causal language, though most often in exclusion clauses. For example, these policies often have limitations of coverage for pre-existing medical conditions. ${ }^{9}$ The insurer may exclude from coverage a disability or a sickness if such was the "result" of some prior illness or condition that existed for some specified period of time prior to the claim.

The limits of language mean that it is often very difficult, ex ante before a loss is claimed, to communicate precisely which losses are covered under an insurance policy. This may be because insurers choose to communicate comprehensive insurance coverage in expansive language like "direct physical loss," "legal liability,” "death resulting from accidental means," or "total disability." This language describes a broad category of occurrences in the world. ${ }^{10}$ Insurers must then use exclusion clauses to carve out those risks not part of that broad coverage. The exclusion clauses that rein in an insurance payout are described not in terms of occurrences, but in terms of losses resulting from some specific set of causal conditions for which the insurer refuses to provide indemnity.

\section{A. Types OF InSURANCE CAUSATION Disputes}

Insurance causation is prevalent in two types of insurance law disputes: coverage disputes and loss distribution disputes. ${ }^{11}$ Insurance coverage disputes involve questions about whether or not a particular insurance policy covers a certain loss. The dispute is between insurer and insured. The dispute can become more complicated in a setting where multiple potential causal inputs are in play in bringing about the loss. For example, a property insurance policy which provides coverage for "direct physical loss" to the property may exclude from coverage any loss caused by "hail." If a severe thunderstorm brings about wind and rain damage to the property, as well as damage by hail, is the end result property damage covered

See e.g. Erik S Knutsen, “Auto Insurance as Social Contract: Solving Automobile Insurance Coverage Disputes Through a Public Regulatory Framework” (2011) 48:3 Alta L Rev 715 at 722 [Knutsen, “Auto Insurance"]. This same coverage clause, however, acts as an exclusion clause in standard non-auto liability insurance policies, to exclude from coverage those losses that the automobile liability insurance policy is expected to cover (ibid at 733). See also Tom Baker, Insurance Law and Policy: Cases, Materials, and Problems, 2d ed (New York: Aspen, 2008) at 466-67 (dubbing these mirrored coverage and exclusion clauses "market segmentation" clauses).

$7 \quad$ Or accident policies attached as common riders on life insurance policies.

8 See e.g. Co-operators Life Insurance Co v Gibbens, 2009 SCC 59, [2009] 3 SCR 605 [Gibbens] (coverage for "bodily injuries occasioned solely through external, violent and accidental means"); Martin v American International Assurance Life Co, 2003 SCC 16, [2003] 1 SCR 158 at para 5 (coverage for death that resulted "directly, and independently of all other causes, from bodily injury effected solely through external, violent and accidental means"); Eric J Adams "The Definition of ‘Accident' in Canadian Coverage Cases and the Unspoken 'Useful Purpose' Test” (2009) 32:2 Dal LJ 417.

$9 \quad$ See e.g. Ellis Estate v Cigna Life Insurance Co of Canada, 2005 NSSC 143, 234 NSR (2d) 72 at para 5 ("No Benefits are payable if Death or a Total Disability results from any Pre-existing Condition(s)"); Van Maele v Alberta Blue Cross Benefits Corp, 2004 ABQB 246, 32 Alta LR (4th) 345 at para 10 ("Long-term disability benefits are not payable for any disability caused by or resulting from a preexisting condition”).

10 McDowell, supra note 1 at 589-90, notes that interpretive challenges with insurance causation could be eliminated if insurers defined coverage in terms of losses and not occurrences.

11 See Erik S Knutsen, "Confusion About Causation in Insurance: Solutions for Catastrophic Losses" (2010) 61:5 Ala L Rev 957 at 965 [Knutsen, “Confusion About Causation”]. 
or excluded by this policy? Hail, an excluded risk, caused some damage to the property. So the coverage dispute would be centred around whether or not the property damage is covered by the policy, whether damage caused by an excluded risk ousts coverage for the entire property loss, or whether just those losses attributable to hail damage are excluded from coverage.

Loss distribution disputes involve contests among multiple insurers as to which insurer will pay for a certain loss. These types of disputes involve overlapping coverage questions. In some loss situations, more than one policy may be called upon to respond to the loss. Discerning which policy (if any) responds to a loss involves answering questions about causation that are important to the respective insurance policies at play in the dispute.

Different types of insurance policies have been designed to respond to different sorts of losses by targeting certain risk pools. There is automobile liability insurance, homeowners liability insurance, and commercial general liability insurance, each covering certain aspects of risk in the world (in other words, liability from automobile operation, personal legal liability, and commercial legal liability). This market segmentation has led to a greater prevalence of loss distribution disputes centering on causation questions. ${ }^{12}$ For example, a commercial liability policy covers most legal liability for injury or property damage for which an insured might become responsible during the course of business. However, that policy often excludes from coverage losses arising from "ownership, use or operation of an ... automobile.” The reason is because automobile liability insurance is the insurance product marketed and experience rated to respond to the risk of auto use. The standard automobile liability insurance coverage clause is worded identically to the commercial liability exclusion clause to signify this market segmentation. The automobile liability policy provides coverage for legal liability arising from "ownership, use or operation of an ... automobile." If a scenario potentially triggers both a commercial and an automobile liability policy, which policy responds to the loss, if any $?^{13}$ While the insured is seeking coverage from either or both the commercial liability and auto insurer, the two insurers are themselves simultaneously involved in a loss distribution dispute, attempting to avoid coverage. Solving coverage or loss distribution disputes rests on being able to predictably assess which causes are important in the insurance law analysis.

An insurance causation analysis is necessarily framed by the wording of the particular insurance policy involved in the dispute. Insureds are incentivized to weave the causal explanation of the loss in order to trigger coverage provisions in the policy. Insurers are incentivized to weave the explanation to trigger exclusions to avoid coverage or to explain the loss as being not caused by a factor covered by the policy. The causal question in insurance, then, is forced by the language of the policy and not something external to the 
policy. ${ }^{14}$ The cause of a loss becomes a semantic interpretive challenge — a linguistic puzzle about the meaning of coverage and exclusion clauses.

Courts in Canada presently utilize two models for interpreting insurance policy language at issue in a legal dispute: a contractual model and a legislative model. ${ }^{15}$ The legislative model is reserved largely for automobile insurance, as these policies are contained in government approved statutes or regulations because automobile insurance is provincially controlled mandatory insurance for drivers. Courts employing the legislative model rely on standard tools of statutory construction when interpreting automobile insurance coverage provisions contained in a statute or regulation. Canadian courts make far more use of the contractual model of insurance policy interpretation. ${ }^{16}$ It involves a two-stage interpretive process for dealing with adhesionary contracts and is thus built with some consumer protection principles in mind.${ }^{17}$ The first "intention" stage attempts to discern the intention of the parties in the bargain, the insurer and the insured. At this stage, a court attempts to use the perceived plain meaning of the insurance policy, read as a whole, to determine what the parties to the policy intended. The second "ambiguity" stage arises only when there is a perceived ambiguity in the wording of the policy. At that stage, to rectify the imbalance of power created by insurer as drafter of an adhesionary contract, courts are to then employ more consumer protectionist interpretation tools. Coverage clauses are to be interpreted broadly and exclusion clauses narrowly. The policy is to be read contra proferentem, as against the insurer who drafted it. The court, in seeking a commercially sensible result, is also to pay heed to the reasonable expectations of the parties.

Disputes about causation in insurance test the limits of the contractual model of interpretation because the very causal language used in the policy demands an abstract analytic exercise. Courts must take the simple causal wording of an exclusion or coverage clause and examine whether or not the actual happenings surrounding the loss trigger those causal descriptors. It would be more effective if courts in Canada moved away from slavish reliance on the fiction of a contractual bargain between insurer and insured and instead adopted more purposive interpretation tools which recognize the social importance of insurance in Canadian society. ${ }^{18}$ That approach would seek to discern the purpose behind a particular insurance policy, the underwriting intent behind a certain clause, and would

14 Malcolm Clarke argues that only the causes mentioned in the coverage or exclusion clauses of a policy should be the focus of the inquiry; other causes are extraneous: Malcolm Clarke, Policies and Perceptions of Insurance Law in the Twenty-First Century (Oxford: Oxford University Press, 2005) at 184. Cases that do not frame the causal factors using the language of the policy as a framework risk skewing the insurance analysis by instead focusing on irrelevant, tort-type causes. See e.g. Kellogg Canada v Zurich Insurance Co (1997), 46 CCLI (2d) 233 (Ont Ct J (Gen Div)) [Kellogg], where the Court found the proximate cause of loss to be the painter's failure to ventilate, but held the loss was excluded from coverage because the damage was caused by contamination.

Knutsen, “Auto Insurance,” supra note 6 at 723.

Ibid.

Ibid at 724-25; Barbara Billingsley, General Principles of Canadian Insurance Law (Markham: LexisNexis Canada, 2008) at 137-39; Craig Brown, Insurance Law in Canada, loose-leaf (consulted on 2 January 2013) (Toronto: Thomson Carswell, 2002) at 8.2. See also Consolidated-Bathurst Export Ltd $v$ Mutual Boiler and Machinery Insurance Co (1979), [1980] 1 SCR 888; Brissette Estate v Westbury Life Insurance Co, [1992] 3 SCR 87; Reid Crowther \& Partners Ltd v Simcoe \& Eerie General Insurance Co, [1993] 1 SCR 252; Non-Marine Underwriters, Lloyd's of London v Scalera, 2000 SCC 24, [2000] 1 SCR 551 [Scalera]; Jesuit Fathers of Upper Canada v Guardian Insurance Co of Canada, 2006 SCC 21, [2006] 1 SCR 744; Derksen, supra note 4; Gibbens, supra note 8; Progressive Homes Ltd v Lombard General Insurance Co of Canada, 2010 SCC 33, [2010] 2 SCR 245.

18 See e.g. Knutsen, “Auto Insurance," ibid at 740-50 (proposing a novel interpretive solution for automobile liability insurance cases which incorporates a purposive component to the analysis). 
completely examine the consequences of a coverage or loss distribution dispute on a systemic level. ${ }^{19}$ Asking whether or not a certain cause in the causal mechanics of a loss is covered or excluded by the wording of an insurance policy often produces less revelatory answers than asking why an insurer would wish that certain cause covered or excluded from coverage.

\section{B. Why CAUSATION IN INSURANCE IS CHALLENGING}

Insurance causation questions become very difficult to sort out because the logic operates backwards to how the insurance claim arises in the first place. To determine whether or not there will be an insurance payout, one must work backward from the loss at hand, examine the policy for possible coverage of that type of occurrence, and then determine whether or not the loss being claimed was caused by an excluded condition.

This is often not simple to do for two reasons. First, there can be a disconnect between the colloquial, non-legal causal story of a loss and the legal analysis of a loss for insurance law purposes. This leads to frequent confusion by courts and litigants because the common sense story about what most people would say caused an accident compellingly distracts one from the more focused and nuanced insurance law causation analysis. Because the insurance policy circumscribes which causes are relevant to the insurance law inquiry, that policy language frames and controls the causation analysis. So causal questions must be framed in reference to the language of the insurance policy, not merely what one might think "caused" a certain loss.

Second, numerous causal forces frequently interact to bring about all but the most straightforward of losses. ${ }^{20}$ It can be difficult to sort out the causal mechanics in a loss. For an all risks property insurer to write a clause to exclude losses caused by sewer backup, the insurer could simply write "we exclude losses caused by sewer backup." In the case of a straightforward sewer backup loss where the sewer backing up is the only causal factor in the insured's flooded basement, the clause is easy to apply and the loss is excluded. Yet, what about the case where a municipal water main bursts, flooding the streets and sewers such that residents get not only toilets backing up into their homes, but water from the water main as well? Is this loss excluded by the "sewer backup" exclusion? Was the loss "caused by sewer backup” (an excluded loss)? Or was the loss caused by the burst municipal water main (a covered loss)? Or both?

See e.g. Engle Estate v Aviva Insurance Co of Canada, 2010 ABCA 18, 469 AR 342 at paras 22-25 [Engle Estate]. The case involved an exclusion for losses caused by earth settlement but the policy was silent as to whether the settlement had to be resulting from natural or human-made factors. The Court took a purposive approach to the exclusion, considered underwriting intent, and examined the very nature of the "all risks" property insurance policy. See also Cabell v The Personal Insurance Co, 2011 ONCA 105, 104 OR (3d) 709 (where an exclusion for damage to a swimming pool would nullify the pool coverage if applied as was literally written).

20 See e.g. Pavlovic v Economical Mutual Insurance Co (1994), 99 BCLR (3d) 298 (CA) [Pavlovic] (coverage for water main loss); Leahy $v$ Canadian Northern Shield Insurance Co, 2000 BCCA 408, 77 BCLR (3d) 44 [Leahy] (no coverage for water damage from a sprinkler system because the exclusion said "caused by," so not cause-dependent; Pavlovic distinguished); Rivard v General Accident Assurance Co of Canada, 2002 MBCA 70, [2002] 7 WWR 395 (damage from leaky swimming pool covered; Leahy distinguished); Jordon v CGU Insurance Co of Canada, 2004 BCSC 402, 10 CCLI (4th) 149 (sewer back-up due to tree roots was excluded because the exclusion was not cause-dependent; Leahy applied); Engle Estate, ibid (coverage for earth settlement); Buchanan $v$ Wawanesa Mutual Insurance Co, 2010 BCCA 333, 321 DLR (4th) 86 (coverage for damage from a leaking water main). 
The causal question is difficult here because the insurer set up the insured's expectation of coverage for water losses by selling “all risk” property coverage which normally covers most damage by water. The coverage clause indicates a broad spectrum of occurrence is covered: “direct physical loss.” So, working backward from the loss, there is an occurrence (the loss, a wet basement) which is covered by the policy's coverage provisions. It is thus up to a properly worded exclusion clause to oust coverage in a clear fashion - if the insurer desires. If asked, the insurer is likely to indicate that it does not wish to underwrite the more fortuitous losses resulting from sewer backup. The difficulty compounds because the insurer used causal language to communicate its desire to exclude the risk of sewer damage from this broad coverage. Because the insurer wants to exclude from coverage certain risks out of the total global risk insured (direct physical loss), it has to exclude a loss based on how the loss occurred, not that it did occur. Coverage in this fact scenario is based on whether or not the loss occurred (in other words, direct physical loss), but the exclusionary language is based on how the loss occurred - its mechanics. This dichotomy of linguistic descriptors makes insurance causation issues difficult to resolve.

\section{Insurance Causation is Not Tort Causation}

Insurance causation is not tort causation. Very often, courts are confused by insurance causation because they attempt to apply concepts from causation in tort law and, as a result, produce inconsistent decisions. ${ }^{21}$ The only reason causation becomes relevant in insurance is because the language of a particular policy has demanded it is relevant for some coverage or exclusionary purpose. It is a linguistic tool for delineating whether or not a certain risk is undertaken by the insurer. The insurer describes a condition in the world which, if it comes about in a certain fashion, triggers insurance indemnity under the policy. It is not a judicially created social duty.

Tort law, however, does involve socially imposed duties. Causation in negligence law is designed to link a tortfeasor's fault with the responsibility for harm that resulted to the injured plaintiff. It is intertwined with the concepts of wrongdoing, blame, and responsibility. ${ }^{22}$ Tort law is supposed to compensate the injured and deter socially unwanted behaviour. These social goals necessarily dictate that many applications of tort causation are, at heart, policy-laden decisions about justice.

$21 \quad$ See Knutsen, “Confusion About Causation,” supra note 11 at 968-72; Jeffrey W Stempel, Stempel on Insurance Contracts, 3d ed (New York: Aspen, 2006) at §7.01; McDowell, supra note 1 at 576-78; Robert H Jerry II \& Douglas R Richmond, Understanding Insurance Law, 4th ed (San Franscisco: LexisNexis, 2007) at 578-80; William Conant Brewer, Jr, "Concurrent Causation in Insurance Contracts” (1961) 59:8 Mich L Rev 1141 at 1142 (arguing that tort causation rules should not be imported into insurance law). See e.g. Tux \& Tails Ltd v Saskatchewan Government Insurance, 2003 SKQB 287, [2004] 2 WWR 437 at para 27 [Tux \& Tails] (the Court considered "but for" and intervening causes in the insurance coverage context); The Owners, Strata Plan NW2580 v Canadian Northern Shield Insurance Co, 2006 BCSC 330, 55 BCLR (4th) 176 [Strata Plan] (distinguishing “direct” from "proximate cause" and analyzing chains of causation in the property claim involving soil compaction); MJ Jones v Royal \& SunAlliance Insurance Co of Canada (2004), 71 OR (3d) 553 (CA) (the insurer used the "but for" and proximate cause concepts to argue that "direct physical loss" was not caused by a marina mistakenly selling the insured's boat).

22 See e.g. Erik S Knutsen, “Clarifying Causation in Tort” (2010) 33:1 Dal LJ 153; John CP Goldberg \& Benjamin C Zipursky, “Torts as Wrongs” (2010) 88:5 Tex L Rev 917; Ernest Weinrib, “The Special Morality of Tort Law” (1989) 34:3 McGill LJ 403; Jules L Coleman, Risks and Wrongs (Cambridge: Cambridge University Press, 1992); HLA Hart \& Tony Honoré, Causation in the Law, 2d ed (Oxford: Clarendon Press, 1985); Ernest J Weinrib, The Idea of Private Law (Cambridge: Harvard University Press, 1995). 
Insurance causation, by contrast, asks an essentially amoral “payout” question. ${ }^{23}$ Did a set of circumstances arise in the world to trigger certain payout language in the insurance policy? An actor's fault, blame, and responsibility are irrelevant in this question. It is a question about whether or not something happened a certain way - the causal mechanics, not the moral valence behind why that thing happened.

Tort causation concepts are often incorrectly imported in liability insurance scenarios. In order to trigger compensation for an injured accident victim, that victim must first trigger a liability insurance policy that covers the alleged tortfeasor's legal liability. So the courts and lawyers are already thinking "tort" by the time the insurance coverage dispute arises. Liability insurance policies use causal language as the filter through which insurance coverage questions must be answered. Whether or not an insured gets coverage for her legal liability flowing from her tort depends on how that liability was caused: through "use and operation of ... an automobile” or caused by "any intentional or criminal act.” Courts and lawyers schooled in tort causation concepts often quickly revert to the fault-based tort causation tools of "but for" cause-in-fact, remoteness (or proximate cause), and intervening acts (novus actus), and apply the doctrine behind those tort tools to interpret the causal language in the insurance policy.

The result of this mishmash of tort and insurance causation is increased systemic cost borne out through increased litigation and unpredictability in the jurisprudence. The use of tort tools forces courts to switch the analysis from a more predictable and commerciallyoriented "payout" question to one of moral "fault.” A classic example is the haphazard and conflicting jurisprudence around the exclusion from liability insurance coverage for losses caused by intentional and criminal acts. ${ }^{24}$ There, courts get distracted by normative questions about blameworthiness of conduct and deterrence of criminals because tort causation doctrine prompts courts to consider the quality of the conduct underlying how a loss was brought about. Another example is the legion of cases surrounding proximate cause in property insurance, where courts attempt to apply tort-like principles of remoteness to chains of causal events leading up to a loss in order to sort out whether the loss was caused by a covered peril. ${ }^{25} \mathrm{~A}$ third example is the countless string of cases interpreting when a loss is caused by "use or operation of an ... automobile," where courts dissect causal chains interrupting other causal chains in tort-like fashion to determine insurance coverage. ${ }^{26}$ Part of the solution to insurance causation disputes is to evaluate causation as a payout trigger while steering clear of inept analogies to tort causation.

McDowell, supra note 1 at 576-78 (insurance causation lies between "liability causation" in tort and "damage causation" in contract); Knutsen, "Confusion About Causation," supra note 11 at 968-72. Knutsen, "Fortuity Clauses," supra note 1.

See e.g. Tux \& Tails, supra note 21. See also Part V.B and note 48, below.

Knutsen, “Auto Insurance," supra note 6. 


\section{Sifting Through THE CAUSAL Mechanics AND Finding THE RELEVANT TARgET CAUSE}

How does one determine what is the cause of a loss in an insurance law context? What if there are multiple causal factors acting together or in sequence to bring about a loss? The key is to analyze cause in reverse. Start from the end result loss claimed, and then work backward in sequence from that end result loss and examine the various relevant causes at play. This is opposite to what is typically done for tort causation in negligence cases. Yet, this makes sense in an insurance law context because causation here is being used solely as a payout trigger located in an insurance policy. The question is whether or not the loss triggers payout. So the causal mechanics are only important in determining how the loss became an insured occurrence as described in the policy, not how the loss "happened" in the narrative, colloquial sense. $^{27}$

Past academic attempts at systematizing causal analysis in insurance law have not caught on. ${ }^{28}$ Common to all, however, is the focus on at least two dimensions of analysis: a temporal dimension and a sufficiency dimension. ${ }^{29}$ Indeed, many Canadian courts search for what they deem a "proximate" cause of the loss, likely in an attempt to indicate the relevant target cause of a loss. ${ }^{30}$ The temporal dimension of a particular cause in a chain of events examines the sequential timing of that cause and its relationship with the end result loss at issue in the claim. When was that cause operative, relative to the other causal mechanics involved in the end result loss? By looking at the temporal nature of potentially relevant causes, and their relationship to the actual loss being claimed, one can begin to place these causes on a continuum to determine relative relevance.

The sufficiency dimension of a particular cause in a chain of events examines whether or not the cause in question really had anything to do with the end result loss claimed. How sufficient is the cause, on its own, in bringing about the end result loss? A cause must be necessarily involved in bringing about the end result loss claimed by the insured. Otherwise, it is not a relevant cause for insurance law purposes. Was the particular cause in question itself sufficient to result in some of the end result harm? Or did the cause need to combine with another cause to result in some end result harm?

The actual loss being claimed is the result of an occurrence. It is the end result damage for which the insured seeks indemnity. For property insurance, it is the result of some external force applied to the property to damage it. For liability insurance, it is the result of

There are numerous examples of when courts perform the analysis in the opposite way and identify a cause first, then proceed with coverage analysis. This leads courts to consider causes not framed within the language of the policy. This also leads courts to weave unhelpful tort-like narratives about chains of causation. See e.g. Aven $v$ Western Union Insurance Co (1999), 13 CCLI (3d) 136 (BCSC) (the proximate cause of the loss was a windstorm, and the rocks and trees which struck the house did so because of the windstorm). See also note 58 below about courts mixing terminology and locating "proximate" cause of loss.

See e.g. Edwin W Patterson, Essentials of Insurance Law, 2d ed (New York: McGraw Hill Publishing, 1957) at 226-71; Brewer, Jr, supra note 21; (categorical approach to causation); Jerry \& Richmond, supra note 21 at 574-77 (two-step, dual filtered approach to causation); Malcolm A Clarke, The Law of Insurance Contracts, 5th ed (London: Informa, 2006) at 796-99 (consecutive is different than concurrent causes; independent is different than interdependent causes). 
some behaviour which gave rise to potential legal liability — bodily injury or property damage resulting from the insured's behaviour. For accident insurance, it is death or injury. Relevance must be guided by the involvement of the cause in bringing about the end result loss claimed - the actual damage. This is because the insurance causation analysis is structured around asking "how" the loss occurred. What were the mechanics of the loss?

After examining the temporal and sufficiency dimensions of a particular cause and its effects on the end result loss being claimed, in the final step, a court should inform its insurance coverage decision by looking at the purpose of the policy, the purpose of the coverage and exclusion clauses at play, and how the coverage result fits into the broader insurance system. ${ }^{31}$ Is this particular insurance product expected to cover this sort of loss? Is another insurance policy to do so instead? What is the insurance underwriting purpose of the clauses at issue and why? If no policy covers the loss, is this the result expected within the insurance system? Does some sort of social insurance cover aspects of this loss? Might the broker who sold the insurance policy be responsible for some or all of the cost and, if so, is that an efficient outcome? Or is the efficient result for the insured to simply lump the cost herself? Where the costs of a loss are ultimately borne is a system-level question far too few courts ask, but which should be a central theme in any dispute about insurance coverage, especially those disputes turning on insurance causation issues. This purposive step, asking how and why a particular insurance policy's coverage fits into the complex compensatory system prevalent in today's society, can actually inform the interpretation of the insurance policy's provisions in those tough interpretive cases.

For example, a vegetable produce provider has commercial property insurance to cover his wares he plans to sell. ${ }^{32}$ The policy provides coverage for "direct physical loss" to, among other things, his produce. A large city-wide electrical blackout occurs because of an overloaded circuit in a far away power generating plant. Electricity stops flowing to the cooling machines that keep the produce fresh. The produce spoils. The produce provider claims the loss under the policy. The insurer denies coverage based on an exclusion for loss caused by "mechanical or electrical breakdown or derangement." The insurer argues that the interrupted electricity could not allow the cooling machines to operate and that is a "mechanical or electrical breakdown or derangement," an excluded cause of the loss.

To solve this coverage dispute, one must first isolate the end result loss being claimed. The end result loss is the spoiled produce, the result of some external force on the property. That is the damage. Then, one works backward from that loss to determine the potentially relevant causes at play in the causal mechanics bringing about the loss. This must be done with reference to the relevant causes potentially triggered by the insurance policy language. So, in this case, the only relevant causes for this particular policy are the blackout (or electricity interruption), which is a covered cause, and the "mechanical or electrical breakdown or derangement," which is an excluded cause. The case becomes a dispute about causal nomenclature, a dispute driven by the policy language. How the blackout occurred

31 For a similar approach to interpretation questions about automobile liability insurance coverage, see Knutsen, “Auto Insurance," supra note 6.

32 See Caneast Foods, supra note 3 (a pickle manufacturer lost produce due to a large southern Ontario power outage); 942325 Ontario v Commonwealth Insurance Co (2006), 81 OR (3d) 399 (CA) [942325 Ontario] (a blackout, not a loss of refrigeration, was the cause of a grocery store loss). 
(for example, that the power generating plant had an overloaded circuit) is not relevant in the analysis. $^{33}$

Next, one examines the temporal and sufficiency dimensions of the two causes at play to determine which is the more sensible causal trigger. For this coverage dispute, sequential timing is not an issue, so the temporal dimension will be less important in sorting out the causal mechanics. The blackout and alleged "mechanical or electrical breakdown or derangement" are really one in the same event. Causal sufficiency, however, is an issue. "Mechanical or electrical breakdown or derangement" on its own is not sufficient to produce the end result loss. It is not necessarily involved in the loss at all. Instead, it is brought about because of the blackout. The blackout, that interruption of electricity, is necessarily involved in bringing about the end result loss. It is causally sufficient, on its own, to produce the end result loss. The "mechanical or electrical breakdown or derangement" is a subsidiary cause totally reliant upon the covered cause, the blackout. The relevant target cause for the analysis is, thus, the blackout.

The final purposive step would lead a court to conclude that this type of loss seems to be just the type of loss a commercial property insurance policy should cover. Excluding from coverage any losses caused by “mechanical or electrical breakdown or derangement” likely indicates that an insurer does not wish to underwrite the risk that an inherent vice in a machine brings about a loss. The machine owner can either service the machine to avoid the moral hazard of a likely breakdown or can turn to the machine manufacturer for recompense. There is, thus, reasoning grounded in fortuity-based insurance underwriting principles for such a choice of phraseology for the exclusion. There are likely no coverage gaps created by this result. By sorting through the causes and attempting to chart them along temporal and sufficiency dimensions, and buttressing the result with a purposive analysis of the insurance policy's role in the broader system, a fact-finder can produce more reasoned, commercially sensible results.

For liability insurance, the end result loss which is the focus of the causal inquiry is the result of the loss-causing behaviour, not the behaviour itself. The temporal moment that is important in the analysis is when the result of the behaviour is activated to cause the loss. Disputes about liability insurance causation issues are most commonly relegated to instances of alleged concurrent cause ${ }^{34}$ involving loss distribution disputes between a non-automobile liability and automobile liability insurer.

In the case of a bar fight where an insured intentionally punches another patron in the face and seriously injures him, a standard homeowners liability insurance policy excludes from coverage losses caused by any "intentional or criminal act." The end result loss in this example is the legal liability to pay for the behavioural result: the personal injuries to the patron. The temporal and sufficiency dimensions are easily satisfied in this example as the insured's intentional punch is certainly necessarily involved in bringing about the end result

33 The Court of Appeal for Ontario found that a "change of temperature” exclusion in a property policy ousted coverage during a blackout for a fruit vendor because the exclusion did not specify how the temperature change was to occur and by what cause: Fresh Taste Produce Ltd v Sovereign General Insurance Co (2005), 27 CCLI (4th) 7 (ONCA). 
of the behaviour here. Thus, the target behaviour, the intentional punch, activated the result. The loss is excluded. The intentional or criminal act must be necessarily involved to activate the end result damage claimed under the policy.

One final example for property insurance may be helpful. A house basement floods because a municipal water main breaks and overtaxes the municipal sewers, causing the house's toilets to back up into the basement. The homeowners property insurance policy provides coverage for "direct physical loss" to the property. The policy excludes from coverage any loss “caused by sewer backup.” Was this loss “caused by sewer backup,” such that it is an excluded loss?

To answer the question, one must first determine the end result loss claimed. The loss, the damage, is the soaking wet basement floor and walls, now tainted with sewer water. That is the result of the occurrence. The occurrence, the sewer backing up, is a covered occurrence under the policy, as it resulted in "direct physical loss" to the property. Drywall will have to be replaced, carpets ripped up, and furniture is damaged. The target cause in the inquiry thus shifts from "municipal water main break" and coverage to the applicability of the "sewer backup” exclusion.

One needs to examine the temporal and sufficiency dimensions of the "sewer backup" cause to determine if the exclusion clause is triggered. The sewer backup was the latest cause in the causal mechanics to actually affect the damaged property. The water main broke and then the sewer backed up. The result of the sewer back up was the flooded, wet basement. On its own, this sewer backup cause is entirely sufficient to result in the end result loss claimed. It is the cause which "touched" the property to damage it. It was entirely necessary and involved in bringing about the end result loss. The exclusion clause does not indicate that it matters how the sewer backup resulted. Therefore, the loss is excluded by the exclusion clause, as it was caused by "sewer backup."

This is also a sensible result on a purposive level because the water main break, which is some antecedent cause in the causal mechanics, was not necessary or sufficient on its own to damage the property. Without the sewer backup, the basement would have been fine. The water from the main would have flowed elsewhere. The water main break is not a relevant cause in this inquiry. For insurance purposes, the end result loss did not occur because of a water main break, but because of the sewer backing up. The policy language is not concerned with how the excluded cause came to be to result in the loss. It is only concerned with whether or not a cause is necessarily involved in bringing about that end result loss. The water main break was not the external force that created the loss.

This result also follows on a purposive level because the insurer was attempting to avoid paying for any losses resulting from sewer backup. Sewer losses can be high-risk, high-value losses in certain areas. For that reason, there are typically additional levels of optional coverage available for this type of loss, which would create an additional experience-rated risk pool. The insurance market provides a solution and the insured probably could have purchased this product for an additional premium. So there is no perceived gap in coverage or in the insurance marketplace. The loss can reasonably lay with the insured who did not purchase that additional sewer water damage endorsement. 


\section{Causation in Automobile InSURANCE}

Canadian courts have created a separate insurance causation doctrine for automobile insurance. The standard coverage clause in automobile insurance policies ${ }^{35}$ grants coverage for liability arising from "ownership, use and operation" of an automobile. ${ }^{36}$ When courts determine the scope of automobile liability coverage in an accident scenario, they utilize a judicially created two-part test: the "purpose" test and the "causation" test. ${ }^{37}$ This test does not appear anywhere in the insurance policy language itself. The purpose test requires that the insured prove that the automobile accident resulted from the ordinary and well-known activities to which automobiles are put. The causation test requires that the insured prove there is some causal relationship, beyond merely incidental or "but for," between the loss and the use or operation of the automobile. So the use of the vehicle must contribute to the injury.

The two-part test is applied differently depending on the type of automobile insurance at issue. If the coverage clause is contained in a first party no-fault accident benefits policy, coverage is construed more broadly. The insured's own vehicle becomes the focus of inquiry and the purpose and causation tests are to be read generously, in favour of coverage. The reason is because no-fault benefits are part of a provincially legislated policy trade-off between allegedly greater access to compensation for accident victims and a reduced (or eliminated) access to tort compensation. If the automobile liability insurance coverage at issue is in a third party liability insurance context, where the insured is seeking coverage for legal liability arising from auto use, the focus of inquiry shifts to that of the insured's behaviour as an at-fault motorist. In order to trigger third party liability insurance coverage, the legal liability must arise from the actions of the insured acting as a motorist. The at-fault motorist's negligence must result in harm to the victim in an unbroken chain of causation.

This results in a more restrictive approach to causation in a third party liability context than in a first party no-fault context. This is justified apparently because the alleged wealth protection of the insured third party is of lesser social importance than the compensatory nature of first party no-fault accident benefits. ${ }^{38}$ This justification is completely misguided because the insured third party's legal liability is only arising because there is some accident victim requesting compensation from that insured. It is bizarre to hold that a no-fault victim is more deserving of compensation than a victim attempting to trigger third party liability insurance compensation through an at-fault motorist.

One could think of the two-part test for interpreting the causal language in a standard automobile liability policy as the court's way of merely chunking the information required to explain the causal relevance of whether or not vehicle use is necessarily involved in bringing about the end result loss claimed in a particular accident scenario. However, the test has become more than that. It does not follow the same coherence as the causation analysis used for other types of insurance. It has become not a causal test, but a descriptor for what

\footnotetext{
35 Both for first party no-fault accident benefits policies and third party liability insurance policies. See Knutsen, “Auto Insurance,” supra note 6 at 720.

See the trio of Supreme Court of Canada decisions establishing the test which interprets the standard automobile insurance coverage clause: Amos, supra note 5; Citadel General Assurance Co v Vytlingam, 2007 SCC 46, [2007] 3 SCR 373 [Vytlingam]; Lumbermens Mutual Casualty Co v Herbison, 2007 SCC 47, [2007] 3 SCR 393. See also Knutsen, “Auto Insurance,” ibid at 735-41. Vytlingham, ibid at para 9.
} 
various courts think automobile insurance should or should not cover. This is, in large part, the result of the importation of tort causation principles that mislead courts in this insurance causation context. The judicially created interpretive test for auto insurance coverage requires courts to examine "chain[s] of causation,"39 think about "but for" causation, and ponder tortlike remoteness issues. ${ }^{40}$ This is a marked departure from what insurance causation is supposed to do: act as a payout trigger. It is also a marked departure from using the policy language as some kind of valence through which to make insurance coverage decisions. The auto liability coverage decisions thus become steeped in unpredictable policy. This has led to many conflicting decisions about automobile insurance coverage. ${ }^{41}$

It would be far better for Canadian law to adopt a more streamlined approach to causation involving assessing the temporal and sufficiency dimensions of a certain auto-related cause. That would keep the analysis consistent with causation as treated in other, non-auto insurance contexts. The present approach has also resulted in the unfortunate recurrence of insurance coverage gaps, primarily when there is a loss distribution dispute between an auto and non-auto liability insurer and both policies contain market segmentation clauses. ${ }^{42}$ The auto insurer's coverage clause is the non-auto insurer's exclusion clause — so interpreting the auto insurance clause broadly or narrowly necessarily affects coverage availability in the other non-auto policy. ${ }^{43}$

Why does Canada treat auto insurance causation differently than other types of insurance $?^{44}$ One reason may be that automobile liability insurance is government-mandated for drivers and the insurance policies are legislatively approved. ${ }^{45}$ Some provinces operate first party no-fault accident benefits programs in lieu of the tort system. All this can give automobile insurance the appearance that it is a regulated public good, the access to which courts must carefully guard. In actual fact, the automobile insurance system is privately funded by premium paying drivers, even if governmentally run, as it is in some provinces. The insurance industry has great influence on the drafting of policy language. The public

$39 \quad$ Ibid at paras 24-25, 37

$40 \quad$ Ibid at paras 12, 29-30.

$41 \quad$ Compare Kopas $v$ Western Assurance Co (2008), 92 OR (3d) 688 (Sup Ct J) (coverage denial turned on the fact that the young boy who was hit by a car in a parking lot had already left the car and arrived at a fence immediately before the accident) with $W u$ (Guardian ad litem of) v Malamas (1985), 21 DLR (4th) 468 (BCCA) (coverage when a child was dropped off and struck by a vehicle), Lefor (Litigation guardian of) v McClure (2000), 49 OR (3d) 557 (CA) (coverage when a child was struck while his mother helped the child cross the street) and Law, Union \& Rock Insurance Co Ltd v Moore's Taxi Ltd, [1960] SCR 80 (a commercial liability policy exclusion for auto use and operation was not applicable when a disabled child was struck by a vehicle after being dropped off by the taxi). See also Hannah $v$ John Doe, 2010 BCCA 141, 318 DLR (4th) 699, where the fact that the victim of a purse-snatching was dragged by the retreating vehicle triggered auto coverage. See also Knutsen, “Auto Insurance,” supra note 6 at 726-28; David M Shoemaker, “'Arising Out of the Ownership, Use or Operation': Tracing the Development and Questioning the Trend of Canadian Automobile Insurance Coverage” (1997) 76:3-4 Can Bar Rev 428.

42 For this reason, McDowell, supra note 1 at 590 suggests that insurers market combination insurance policies that cover the entire scope of automobile and homeowners liability in one self-contained policy. See e.g. Ricketts $v$ Moore (2001), 56 OR (3d) 78 (CA) (legal liability arising from an accident with a child's toy go-kart triggered an auto use exclusion under a homeowners liability policy; auto liability insurance would never cover this type of accident, so the injured victim is left uncompensated by the gap created by a broad interpretation of this exclusion clause). See also Knutsen, “Auto Insurance,” supra note 6 at 733-35.

44 Canada is, in fact, unique in its double-pronged test for interpreting automobile insurance coverage. See Knutsen, “Auto Insurance,” ibid, n 95 (American jurisdictions utilize either a purpose or a causation test for auto insurance coverage, not both tests). Ibid. 
character of the insurance should not be a valid excuse to depart from what should otherwise be the consistent application of legal principles of insurance causation.

The other reason auto liability causation may be treated differently by courts could simply be that courts perhaps feel compelled to create some limits on what automobile liability insurance "should" cover, because the coverage clause is drafted in such broad causal language. The ubiquitous vehicle is so frequently involved in losses that a dizzying number of claims surely must have a vehicle somewhere in the causal mechanics leading up to the loss. Yet, to get around the seemingly unlimited nature of this insurer-drafted coverage clause, should courts really be creating additional, specialized interpretations of causation that are not found in any automobile insurance policy language? ${ }^{46}$

\section{ConCURRENT CaUSATION IN InSURANCE}

\section{A. What is Concurrent Causation in InSURANCE?}

Many insurance losses are not the result of a single cause of loss. Concurrent causation occurs when a loss is brought about through a combination of two or more potential causes. Three situations can give rise to disputes about concurrent causation. ${ }^{47}$ First, a coverage dispute can arise when two or more concurrent causes appear to act together in some combination to lead to a loss and at least one cause may be covered under an insurance policy. The other causes may either be excluded or simply not covered by the policy. Second, a coverage dispute can also arise when not all of the separate concurrent causes in the causal mechanics leading up to a loss are covered under an insurance policy. Finally, a loss distribution dispute among insurers can arise when a loss arising from concurrent causes appears to be covered by two or more different insurance policies. Insurance market segmentation has led to these loss distribution disputes becoming common between auto and non-auto liability insurance policies. The loss allegedly covered by one applicable insurance policy appears to be simultaneously excluded by the other.

\section{B. CANAdA's ApPRoACH TO CONCURRENT CAUSATION}

The Supreme Court of Canada in Derksen set out a workable solution to concurrent causation that fits with the conceptual structure of the process described above for solving general insurance causation disputes. In Derksen, a worker was insured by his commercial general liability policy and his automobile liability policy. While doing road work, the worker placed a heavy sign base on the tongue of a towed air compressor. Instead of loading the sign base into the vehicle, he accidentally left the base on the air compressor and began to drive. The sign base suddenly popped up from the air compressor, flew into the air, and struck an oncoming school bus. One child was killed and three others seriously injured from the flying sign base. ${ }^{48}$ There were thus two potential liability insurance policies which may have covered the end result loss: an automobile liability policy and a commercial general liability policy. The commercial general liability policy covered the worker for legal liability 
from his behaviour, but excluded losses arising from the "use and operation" of an automobile. The automobile liability policy covered the worker only for liability arising out of the "use and operation" of an automobile. ${ }^{49}$

The Supreme Court held that the end result loss was the result of two concurrent causes: the worker's negligent work-site cleanup (a cause covered under the commercial general liability policy) and his negligent operation of an automobile (a cause covered under the automobile liability policy). Both policies provided coverage and had to respond to the loss because both causes acted together concurrently to produce the loss. ${ }^{50}$ So if one cause in a concurrently caused loss is a covered cause and other causes are excluded or non-covered causes, the insurance policy must respond to the loss. ${ }^{51}$

In crafting this liberal approach ${ }^{52}$ to solving coverage questions about concurrent causation, the Court rejected two other approaches which had featured in past Canadian and British jurisprudence. It refused to adopt a more conservative approach whereby if one cause in a concurrently caused loss is an excluded cause, the exclusion applies, regardless as to whether other concurrent causes are covered causes. ${ }^{53}$ The Court also rejected the “dominant” or "proximate cause” approach to causation. ${ }^{54}$ That approach has been criticized

$49 \quad$ Ibid at para 13.

$50 \quad$ Ibid at paras 37, 55-56

51 See also Djepic v Kuburovic (2006), 80 OR (3d) 21 (CA) (both homeowners and automobile insurance policies owed a duty to defend the insured when a bungee cord used to secure a mattress on a van struck a victim in the eye, because using the cord could be a non-auto related action covered under the homeowners policy).

52 Knutsen, “Confusion About Causation,” supra note 11 at 976-77 (calling the four possible approaches to concurrent causation "liberal," “conservative,” “dominant cause” and “apportionment”). See also Jerry \& Richmond, supra note 21 at 567-92.

53 In doing so, the Court rejected or distinguished a number of Canadian cases relying on this conservative approach: Ford Motor Co of Canada Ltd v Prudential Assurance Co, [1959] SCR 539; Lizotte v Traders General Insurance Co, [1986] 3 WWR 546 (BCCA) [Lizotte]; Clark's Chick Hatchery Ltd v Commonwealth Insurance Co (1982), 40 NBR (2d) 87 (CA); Goodman v Royal Insurance Co of Canada, [1997] 8 WWR 69 (Man CA). In addition, the Court rejected the British case of Wayne Tank and Pump Co Ltd v Employers Liability Assurance Corporation Ltd, [1973] 3 All ER 825 (CA) [Wayne Tank], in which that Court discussed applying both a conservative and dominant cause approach to causation. Britain follows the conservative approach to concurrent causation stemming from Leyland Shipping Co, Ltd v Norwich Union Fire Insurance Society, Ltd, [1918] AC 350 (HL), likely because of that jurisdiction's staunch adherence to a contractual approach to insurance policy interpretation without a Canadian or American consumer protectionist focus. See e.g. Malcolm Clarke, "Insurance: The Proximate Cause in English Law” (1981) 40:2 Cambridge LJ 284; Raoul P Colinvaux, Colinvaux’s Law of Insurance, Robert Merkin, ed, 7th ed (Oxford: Hart Publishing, 1997) at 118-19; John Lowry \& Philip Rawlings, Insurance Law: Doctrine and Principles, 2d ed (London: Sweet \& Maxwell, 2005).

54 As featured in the British Wayne Tank decision, ibid, as well as a number of other Canadian decisions, including The Sherwin-Williams Co v Boiler Inspection and Insurance Co of Canada, [1950] SCR 187 at 202, which held:

The law, from all the causes leading up to a result, selects that which is direct or proximate and regards all the others as remote. The direct or proximate cause may not be the last, or, indeed, that in any specified place in the list of causes but is the one which has been variously described as the "effective", the "dominant" or "the cause without which" the loss or damage would not have been suffered.

In Derksen, supra note 4, the Supreme Court of Canada relied on CCR Fishing Ltd v British Reserve Insurance Co, [1990] 1 SCR 814 at 823 [CCR Fishing]:

The question of whether insurance applies to a loss should not depend on metaphysical debates as to which of various causes contributing to the accident was proximate. Apart from the apparent injustice of making indemnity dependent on such fine and contestable reasoning, such a test is calculated to produce disputed claims and litigation. 
by many academic commentators ${ }^{55}$ and by the Supreme Court of Canada as producing unpredictable results based on abstract causal "metaphysical debates." 56 Dominant cause analysis asks the court to choose the dominant cause among the various causes at issue. The choice of the dominant cause drives the coverage analysis because coverage for the loss is then dependent on whether or not the insurance policy covers the loss resulting from that particular dominant cause. The dominant cause is supposed to be the main or effective cause which sets the events in motion. A glance at the legion of convoluted decisions applying the dominant cause approach shows how unpredictable its application is. ${ }^{57}$ Although a number of Canadian courts have applied the dominant or proximate cause approach to concurrent causation in the past, those decisions should now be ignored. ${ }^{58}$ The Supreme Court's rejection of the dominant cause approach to insurance coverage in Derksen certainly cannot be relegated only to instances of concurrent causation in liability insurance. A number of courts since Derksen have rightly refused to apply a dominant cause analysis to insurance causation disputes. ${ }^{59}$ The reasons why the Supreme Court rejected the dominant cause approach in that case's context apply equally to insurance cases about property and other insurance policies as well.

\section{IdENTIFYING THE ConcurRent CAUSATION CASE}

Most insurance loss situations do not involve losses arising from concurrent causes. However, insureds are incentivized to spin the causal story as a concurrent causation situation to take advantage of the liberal approach to coverage from Derksen — as long as one cause is covered, the insurance policy must respond. For causes to be concurrent for

See e.g. Joseph Lavitt, “The Doctrine of Efficient Proximate Cause, the Katrina Disaster, Prosser’s Folly, and the Third Restatement of Torts: Cracking the Conundrum” (2008) 54:1 Loy L Rev 1; Jerry \& Richmond, supra note 21 at 560-66; Knutsen, "Confusion About Causation," supra note 11; Stempel, supra note 21 at \$7.02; Clarke, supra note 14 at 185-87; Richard A Fierce, "Insurance Law Concurrent Causation: Examination of Alternative Approaches" (1985) 10:3 S Ill ULJ 527 at 544-45. But see Peter Nash Swisher, "Insurance Causation Issues: The Legacy of Bird v St Paul Fire \& Marine Ins Co" (2002) 2:2 Nevada Law Journal 351 (advocating for a middle ground "dominant cause" approach to insurance causation, as such best fits with the reasonable expectations of the parties); Peter Nash Swisher, "Judicial Interpretations of Insurance Contract Disputes: Toward a Realistic Middle Ground Approach" (1996) 57:2 Ohio St LJ 543 (multiple rules for concurrent causation can be explained by the debate between formalism and functionalism); Peter Nash Swisher, "Judicial Rationales in Insurance Law: Dusting Off the Formal for the Function” (1991) 52:4 Ohio St LJ 1037; Jerry \& Richmond, ibid at 574-78 (proposing an approach to insurance causation that seeks to determine a dominant cause as a first step, only to be abandoned if it proves too difficult).

$56 \quad$ Derksen, supra note 4 at para 36, citing CCR Fishing, supra note 54 at para 823.

57 See e.g. Kellogg, supra note 14 (where the Court found the proximate cause of loss to be a painter's failure to ventilate but held that the loss was excluded because the damage was caused by contamination and pollution, which were excluded causes).

58 Despite the Derksen Court's clear rejection of dominant cause analysis, some courts have continued to search for a "proximate" or "dominant" cause of a loss, even in instances not involving concurrent causation allegations. It may be that courts do not intend to perform a dominant cause analysis and are merely using the term "proximate" or "dominant" to indicate the relevant cause of the loss. However, use of such terminology will hopefully eventually be negated as it breeds confusion with the separate doctrinal processes of both concurrent causation analysis and tort causation. See e.g. Hanlon v ING Insurance Co of Canada, 2011 BCSC 73, 93 CCLI (4th) 93 (where the "dominant cause" of damage was a drug grow operation); 942325 Ontario, supra note 32 (a blackout, not loss of refrigeration, was the "proximate" cause of a grocery store loss); Rainbow Technicoloured Wood Veneer Ltd v Guardian Insurance Co of Canada, 2002 FCA 28, [2002] 288 NR 17 (bad weather was not a contributing proximate cause of a loss to ship cargo because it was expected); Continental Insurance Co $v$ Almassa International (2003), 46 CCLI (3d) 206 (Ont Sup Ct J) (where the proximate cause of lumber damage was not delay, but a failure to ventilate).

$59 \quad$ See e.g. B \& B Optical Management Ltd v Bast, 2003 SKQB 242, [2004] 6 WWR 747 (the proximate cause analysis was rejected as per Derksen in favour of a liberal approach to concurrent causation in a property insurance loss that resulted from incorrect voltage hookup on machinery). 
liability insurance purposes, the alleged concurrent causes must each be stand-alone acts of negligence where each act is itself capable of supporting a separate and distinct legal claim. ${ }^{60}$ The causes must each be something for which the insured could expect to be sued. A court can determine this by examining the temporal and sufficiency dimensions of potential concurrent causes to determine if the causes are in some relevant temporal relationship with each other and if each are necessarily involved in the end result loss. ${ }^{61}$ This was the case in Derksen, where a worker committed two distinct acts of negligence: negligent operation of an automobile and negligent worksite cleanup. Each act of negligence itself was necessarily involved in bringing about the end result loss to the degree that each could prompt a separate, stand-alone lawsuit for negligence. ${ }^{62}$

For causes to be concurrent for property insurance purposes, the analysis is somewhat simpler because drafters of property insurance can tune relevant exclusionary language to more surgically describe the external force which brought about the excluded loss (for example, loss caused by “wind," “pollution,” or "sewer backup”). ${ }^{63}$ Courts should analyze the temporal and sufficiency dimensions of the various alleged concurrent causes in order to assess whether or not the causes have some relationship between them such that they are truly concurrent (and not merely totally unrelated causes occurring in some series). For the temporal dimension, the cause can either be a serial or parallel cause. ${ }^{64}$ Serial causes occur in a sequence over time, one after the other. A house first damaged by lightning (a covered cause) in a severe storm may then be flooded by the rising water of a river running behind

See e.g. V-Twin Motorcycle School Ltd v Ins Corp of British Columbia, 2010 BCSC 725, 85 CCLI (4th) 280 [V-Twin]; Aviva Insurance Co of Canada v Pizza Pizza Ltd, 2008 ONCA 535, 91 OR (3d) 161 [Pizza Pizza]; TR Construction, supra note 5; McLean (Litigation Guardian of) v Jorgenson (2005), 78 OR (3d) 308 (CA) [McLean]; Unger (Litigation Guardian of) v Unger (2003), 68 OR (3d) 257 (CA) [Unger]; 430937 Ontario Ltd v Zurich Insurance Co, 2012 ONSC 3093, 10 CCLI (5th) 296 (trailering a fuel truck was not separate conduct equating to concurrent liability for commercial general liability policy). But see Sommerfield v Lombard Insurance Group (2005), 74 OR (3d) 571 (Sup Ct J) [Sommerfield] (the Court found that allegations of both negligence and intentional torts could be separate causes of action where a teacher was sued for both professional negligence in not reporting another teacher's sexual abuse and for sexual battery).

61 See e.g. CUMIS General Insurance v 1319273 Ontario Ltd, 2008 ONCA 249, 91 OR (3d) 147 [CUMIS] (commercial general liability coverage was denied because failure to securely load a ladder was not considered to be a separate act from the automobile use; automobile use was an excluded cause). One recurring concurrent causation allegation involves a claim for negligent supervision among the alleged concurrent causes in an injury case. A common example is a lawsuit against both child and parents for the child's intentional assault on another. The child's actions may be excluded from liability insurance coverage because the child acted intentionally to bring about the loss (an excluded cause). However, the claim for negligent supervision by the parents can be necessarily involved in bringing about the particular end result physical harm to the assaulted victim to such a level that it is a separate and distinct act of negligence. Failing to supervise the activity can, in many instances, set the stage for the harm to occur in such a way that the lack of supervision is necessarily involved in the end result loss, and thus a relevant concurrent cause. See e.g. Durham District School Board v Grodesky, 2012 ONCA 270, 110 OR (3d) 76 [Durham District] (the parents' negligent supervision was a separate negligent act from the child's intentional act of setting the fire); Pender (Guardian Ad Litem) v Squires, 2011 NLTD(G) 23, 304 Nfld \& PEI 282; Morrow (Litigation Guardian of) v Symons (2007), 54 CCLI (4th) 188 (Ont Sup Ct J); Pictou County Farmers' Mutual Fire Insurance Co v Williams, 2001 NSCA 33, 191 NSR (2d) 390. But see Co-operators Gen Insurance Co v Murray (2007), 86 OR (3d) 255 (Sup Ct J) [Murray]; Thompson v Warriner, [2002] OJ no 1769 (QL) (CA) [Thompson]; Clausen v Royal \& SunAlliance Insurance Co of Canada (2004), 73 OR (3d) 611 (Sup Ct J); Weeks v Aviva Canada, 2006 NSSC 83, 243 NSR (2d) 312 [Weeks], where the court did not uphold a separate claim for negligent parental supervision. In those cases, it appears the courts mistakenly confused the law about causation with the law about pleadings sufficiency as discussed below, thinking the supervision was "subsumed" into the other conduct. In Weeks and Murray, because a motor vehicle was the instrument of harm, the courts incorrectly held that the negligent supervision was "subsumed" into the vehicle use such that the parents' conduct was not separable. 
the house ("flood," an excluded cause). The lightning and flood are serial causes, happening one after the other. Parallel causes, by contrast, are indivisible along a temporal continuum and are more readily recognizable as often being true concurrent causes. The causal mechanics occur at the same time, not in sequence, but simultaneously. Fire and smoke damage frequently are parallel concurrent causes of a loss, as both act at the same time to damage the property. Determining the temporal dimension of a concurrent cause (either serial or parallel) gives a court valuable information about the cause's relationship to both the other alleged concurrent causes and the end result loss claimed. ${ }^{65}$

Examining the sufficiency dimension of the alleged concurrent causes ensures that each must be somehow necessarily involved in bringing about some of the end result loss. Yet, because the subject insurance is property insurance, which insures against external forces acting on the property, the level of sufficiency required to be a true concurrent cause should not be an all-or-nothing question. Different concurrent causes can result in different aspects of the claimed damage in a property insurance claim. Lightning causes different damage than the flood. The end result loss claimed is the total house damage, but the lightning may have caused some burn damage and the flood caused some water damage to the property. As long as an alleged concurrent cause results in some end result damage to the property, it should be a cause sufficient for coverage analysis. Under the Canadian liberal approach to concurrent causation, the house damaged by both lightning and flood would attract property insurance coverage for the loss. Each cause is sufficient to result in some damage, even though each acted serially, one after the other. There was some relationship between the causes and the end result damage claimed. Because one concurrent cause is a covered cause, the loss is covered even though the excluded cause (flood) acted in concert to bring about the end result loss.

\section{INDEMNITY FOR THE CONCURRENTLY CAUSED LOSS}

The Supreme Court in Derksen indicated that, for indemnity or payout purposes, insurers whose policies cover a concurrently caused loss are only responsible to pay for that portion of the loss which corresponds to the risk undertaken in the insurance policy. ${ }^{66}$ This apportionment approach is a sound approach for property insurance losses, but is problematic in practice for liability insurance losses. ${ }^{67}$

See e.g. Strata Plan, supra note 21 (loss due to soil compaction was caused by successive but not concurrent causes); Chandra v Canadian Northern Shield Insurance Co, 2006 BCSC 715, 36 CCLI (4th) 242 (loss was caused by a continuous water leak and mould; the concurrent cause of contractor negligence was not relevant); Algonquin Power (Long Sault) Partnership v Chubb Insurance Co of Canada (2003), 50 CCLI (3d) 107 (Ont Sup Ct J) (the cause of a dam failure was faulty design and not other serial causes leading up to the loss). The temporal sequences of concurrent causes is also important to Mark Bell's categorical approach to concurrent causation in property insurance (Mark M Bell, "A Concurrent Mess and a Call for Clarity in First-Party Property Insurance Coverage Analysis” (2011) 18:1 Conn Ins LJ 73).

$66 \quad$ Derksen, supra note 4 at para 56.

67 Lowry \& Rawlings, supra note 53 at 233-34 (the authors argue at 233-34 that indemnity for property insurance should be treated differently than indemnity for liability insurance). 


\section{APPORTIONING INDEMNITY FOR DISCRETE CONCURRENT CAUSES IN PROPERTY INSURANCE}

Often, concurrently caused losses in property insurance are brought about by discrete concurrent causes, as opposed to reciprocal concurrent causes featured in most concurrently caused losses claimed in liability insurance contexts. A loss caused by discrete concurrent causes is born of independent, individually sufficient causes. Each separate cause, on its own, may produce some portion of the loss, but not the total cumulative loss in its entirely. For example, if lightning strikes a house and damages it in a serious storm, and then the house is flooded by the swelling nearby river, both lightning and the flood damaged the property to some degree. The end result loss claimed is the combination of the results of the two causes - the external forces acting on the property.

Apportionment of indemnity makes sense for losses caused by discrete concurrent causes in a property insurance loss because that approach avoids the temptation to divide the causes in an all-or-nothing approach based on some sort of tort-like causal responsibility. Courts are tempted to apply tort causation and remoteness principles because either covering or excluding the entire loss somehow seems unfair to either insured or insurer when part of the loss is clearly resulting from a discrete, covered cause. If lightning is a covered cause and burned up some of the house but then a flood, an excluded cause, results in massive water damage to the home, should the insured receive coverage or not? The causes are separated in effect but cumulative in end result total loss.

The hallmark of a discrete concurrent cause is that its result is divisible from results of other discrete causes. Indemnity questions can thus be answered on a "per-cause” basis and the unfair all-or-nothing result avoided. The process would be identical to that currently done for comparative negligence in tort. The key would be to tie the apportionment to the total end result dollar value of damage claimed for the loss. So if the lightning strike resulted in 20 percent of the end result total property damage and it is a covered cause, the insured receives 20 percent of the indemnity for that total loss, regardless of the fact that the flood resulted in 80 percent of the house damage and is an excluded cause. This apportionment approach necessarily rests on the analysis working backward from the end result total loss and then apportioning the loss based on the relevant causes necessarily involved in that loss.

Using apportionment for losses resulting from discrete concurrent causes is efficient for a number of reasons. ${ }^{68}$ Disputes about discrete concurrent causes are largely relegated to the property insurance market, where it may actually be possible to obtain reliable information about the role various external forces played to bring about the end result loss. Property insurance exclusions are more surgically tuned to describing the insured risk than exclusions in broad-spectrum liability insurance. It is easier to apply an exclusion for losses arising from

68 A number of academic commentators have suggested an apportionment approach to indemnity for concurrently caused losses. See e.g. Knutsen, “Confusion About Causation,” supra note 11 at 1010-12; Fierce, supra note 55 at 544-45; Mark Y Umeda, "Concurrent Proximate Causes in Insurance Disputes: After Garvey, What Will Policyholders Expect?” (1989) 29:2 Santa Clara L Rev 423, 453-56; Anthony J Saunders, “Proximate Cause in Insurance Law — Before and After Derksen” (2006) 32:1-2 Advocates' Q 140 at 166. Canadian courts have also skirted with this idea. See e.g. Lizotte, supra note 53. Texas follows an apportionment rule, where an insured must prove the proportion of the loss covered. See Randall L Smith \& Fred A Simpson, “Causation in Insurance Law” (2006) 48:2 S Tex L Rev 305 at 322. 
hail than it is for losses arising from intentional acts. The small investment in additional information costs for discerning contribution of lightning on the end result house loss may, in the long term, lead to a more fair distribution of costs in the overall insurance market because an all-or-nothing result is avoided in a loss resulting from concurrent causes. Both coverage and exclusion clauses in insurance policies are given effect, which allows insurers to better underwrite the risk. Gaps in coverage are also largely eliminated, as only the applicable portions of a respective policy are triggered.

It is possible that some property insurance losses may result from reciprocal concurrent causes. Causes may come together interdependently where each on its own would not have resulted in any loss, but the combination of the causes did. These instances are probably very rare in property insurance, relegated to total loss situations such as large scale property disasters where the information costs are too high to sensibly isolate the involvement of the alleged causes on the end result loss claimed. In those few instances, where reciprocal concurrent causes bring about the loss, courts should ensure that losses are shared equally among the relevant insurance policies triggered, as noted below for sharing indemnity for losses in a liability insurance context.

\section{SHARING INDEMNITY RATABLY FOR RECIPROCAL CONCURRENT CAUSES IN LIABILITY INSURANCE}

The apportionment approach to indemnity does not work for a Derksen-type loss, where the concurrent causes are reciprocal in nature. This is because the end result loss is not sensibly divisible on a cause-by-cause basis. Reciprocal causes are interdependent, individually insufficient causes. These causes act together and, without both, the end result loss would not have occurred. In Derksen, how does one divide indemnity responsibility of the end result loss amongst the two competing concurrent causes - negligent auto use and negligent worksite cleanup? Was the negligent auto use more "responsible" for the loss than the negligent worksite cleanup? What percentage of responsibility does one assign to each cause (and thus to each insurer)? In Derksen, both the negligent driving and negligent worksite cleanup were necessarily involved in order to bring about the end result loss. Having just one cause or the other would have resulted in no loss at all. Who can say whether the negligent driving was more necessarily involved as a cause of the end result loss than the negligent worksite cleanup? To ask the question places one squarely back into the "metaphysical debates" that occurred under the dominant or proximate cause approach to concurrent causation.

The most efficient solution for losses resulting from reciprocal concurrent causes is to divide the payment responsibility equally among all contributing insurers. Given that liability insurance coverage questions tend to be more complicated to answer because the target of the insurance is behaviour and not an isolated external force on property, the information costs of apportioning reciprocal causes are inexorably high - or perhaps impossible to calculate. It is more efficient, predictable, and fair to follow the Supreme Court's lead in Derksen in applying a liberal approach to concurrent causation coverage and carry the logic through to the indemnity question. Thus, losses resulting from reciprocal concurrent causes should be paid for equally by each triggered liability insurance policy. This would eliminate the costly incentive to litigate the payout fallout from disputes like Derksen. This would also 
avoid inefficient and unexpected gaps in insured coverage, a particularly salient benefit when broad spectrum liability insurance is expected to be the backbone of the tort compensation system. $^{69}$

\section{E. Contracting Out of Concurrent Causation}

Despite the Supreme Court's indication that carefully drafted insurance policy language may have assisted the commercial general liability insurer in Derksen in excluding from coverage losses resulting from automobile use and operation, it is not at all certain that drafting alone would side-step the application of Canada's liberal approach to concurrent causation coverage. In fact, the wisdom of drafting insurance policy language to circumvent concurrent causation is itself questionable when one examines the legal issues raised by doing so.

The Derksen court cited the exclusion clause featured in Pavlovic as an example of language the insurer could have used to more clearly indicate that losses concurrently caused by automobile use were excluded from liability insurance coverage: "We do not insure for such loss regardless of the cause of the excluded event, other causes of the loss, or whether other causes acted concurrently or in any sequence with the excluded event to produce the loss." ${ }^{70}$ This is a typical anti-concurrent causation clause, designed to circumvent the application of a liberal approach to concurrent causation. ${ }^{71}$ However, the actual effect of such exclusions may be hollow in practice. A number of Canadian courts have not given effect to such clauses. ${ }^{72}$ In the United States, a surprising number of courts also invalidate anticoncurrent causation clauses. ${ }^{73}$ There are various reasons that courts do so. First, such clauses can create unreasonable gaps in insurance coverage, particularly in loss distribution disputes involving obvious market segmentation among the policies, as was the case in Derksen between the auto and non-auto liability policies. In that case, to have neither policy respond to the loss would be a troubling result; there was no other commercially available insurance

The Supreme Court in Derksen, supra note 4 at para 58 made specific note that the commercial general liability insurance policy and automobile liability insurance policy at issue in the dispute were both meant to be complementary sources of insurance. Gaps in coverage should be avoided in these instances. See also Knutsen, "Confusion About Causation," supra note 11 at 986-93 (explaining the inefficiencies in offloading indemnity costs to other insurance markets).

$70 \quad$ Pavlovic, supra note 20 at para 23, cited in Derksen, supra note 4 at para 47.

71 The anti-concurrent causation clause could also contain exclusionary causal language such as "contributed to," "resulting in any combination with," "directly or indirectly," "aggravated by," or "resulting from," in order to attempt to signify that a certain cause of a loss excludes the loss from coverage, no matter how that cause functions in the causal mechanics of the loss.

72 See e.g. Canevada Country Communities v GAN Canada Insurance Co, 1999 BCCA 339, 68 BCLR (3d) 94 (the interpretation of "direct cause" language was incongruous with the interpretation of "directly or indirectly" language; "directly or indirectly" language was read narrowly); Tux \& Tails, supra note 21 at paras 22-23 (narrow reading of "directly or indirectly" language in exclusions); Appin Realty Corp $v$ Economical Mutual Insurance Co, 2007 CarswellOnt 9329 (WL Can) (Sup Ct J), aff'd 2008 ONCA 95, 89 OR (3d) 654 (the duty to defend arose in a liability case about illness from mould and bacteria, despite an anti-concurrent causation clause in the policy); Day $v$ Wood (2008), 92 OR (3d) 438 (Sup Ct $\mathrm{J}$ ) (the duty to defend in a liability case about illness from mould and bacteria, despite an anti-concurrent causation clause in the policy); Engle Estate, supra note 19 ("directly or indirectly" language did not demonstrate an insurer's intent to exclude those losses arising from earth settlement that were caused by human-made factors; the clause was read narrowly). Contrast with Strata Plan, supra note 21 (a "directly or indirectly" anti-concurrent causation exclusion clause was upheld) and Minox, supra note 5 ("directly or indirectly" means that both direct and consequential loss of an event are captured; concurrent causes were excluded by this wording).

73 See Knutsen, “Confusion About Causation," supra note 11 at 995-97; Stempel, supra note 21 at §7-20, $\S 7-21$. 
the insured could have purchased to cover what one would reasonably think would be a risk covered by both policies.

Second, the rules of insurance policy interpretation have strong consumer protectionist overtones. ${ }^{74}$ Anti-concurrent causation clauses can sometimes smack of unfairness. Few insureds, ex ante, could ever predict the eventual effect of such a clause at the time of the purchase of the policy. Therefore, when such a clause exists in a contract of adhesion and is so clearly drafted solely for the benefit of the insurer, and where an insured could not foresee the eventual trigger of such a clause, should courts uphold it? ${ }^{75}$ The injustice appears all the more salient if the excluded clause only played a very minor role in the end result total loss. For example, if an all-risks property policy excludes from coverage loss arising "directly or indirectly, or in any combination with, mould" and 10 percent of the end result damage to the property resulted from mould and 90 percent from some other covered cause, denying an insured coverage for having the misfortune of mould touching one-tenth of the damaged property seems unreasonable when the insurer took a premium to underwrite 90 percent of the risk that did materialize.

Third, anti-concurrent causation clauses are drafted by insurers to circumvent the common law. The Supreme Court of Canada has indicated that a liberal approach to concurrent causation coverage questions is to be undertaken. Could one then, by insurance drafting, revert back to a more conservative approach to concurrent causation, the very approach rejected by the Supreme Court? A number of American states have invalidated these clauses by holding an insurer cannot attempt to dodge immutable doctrinal insurance law rules about concurrent causation at the unpredictable expense of policyholders’ rights. ${ }^{76}$

Adopting an apportionment approach to property insurance losses resulting from discrete causes eliminates the need for anti-concurrent causation clauses in property insurance policies. Losses are apportioned by the relevant causes. If mould results in 10 percent of the loss, the insurer does not indemnify for that 10 percent. Anti-concurrent causation clauses in liability insurance policies are particularly insidious because they would completely circumvent the Supreme Court of Canada's liberal approach to coverage when the loss results from reciprocal concurrent causes. Because liability insurance insures against legal liability resulting from an insured's behaviour, and the causal mechanics of tort liability can be as varied as human behaviour itself, all sorts of behaviour one would expect would be insured by comprehensive liability insurance would then be excluded if somewhere in that causal matrix an excluded cause played some role. Courts would be wise to keep in mind that the purpose behind exclusions for comprehensive liability insurance coverage are nearly always linked to an insured's ability to control his or her own behaviour, thereby preventing

74 See e.g. Peter Nash Swisher, "Causation Requirements in Tort and Insurance Law Practice: Demystifying Some Legal Causation 'Riddles'” (2007) 43:1 Tort Trial \& Insurance Practice Law Journal 1 at 27-29 (anti-concurrent causation clauses can produce extreme coverage results which can prompt courts to overreact and construe the clause narrowly).

See e.g. McDowell, supra note 1 at 579 (arguing that courts should not uphold these clauses for this reason).

See e.g. Murray v State Farm Fire \& Cas Co, 509 SE (2d) 1 (W Va 1998); Howell v State Farm Fire \& Casualty Co, 267 Cal Rptr 708 at 711-12 (Cal Ct App 1990). See also Saunders, supra note 68 at 162 (Canadian courts would likely read down any anti-concurrent cause clause, particularly if it featured the "directly or indirectly” causal language). See also Cal Ins Code §530 which indicates that the liberal approach to concurrent causation is to be applied unless the policy says otherwise. 
indemnity for both non-fortuitous losses and moral hazard issues. ${ }^{77}$ The eventual sensible result may be that Canadian courts will follow the line of American courts which continue to invalidate anti-concurrent causation clauses in the liability insurance context.

\section{Pleadings and Causation in Insurance}

Courts often decide insurance causation disputes at the pleadings stage, before any factfinding takes place in the dispute resolution process. This gives the pleadings stage heightened importance because initial coverage decisions resting on causation issues are often founded without evidence on alleged facts only. The law surrounding pleadings sufficiency in insurance coverage has frequently been erroneously imported into some courts' insurance causation analyses for coverage and indemnity purposes ${ }^{78}$ It is, thus, key to keep the pleadings evaluation a distinct process from actual coverage and indemnity determinations.

The importance of the pleadings stage in many insurance causation disputes produces somewhat perverse incentives to over- or under-plead a case in order to either trigger coverage $^{79}$ or avoid coverage. ${ }^{80}$ The spin-off effect of these practices creates varying degrees of difficulty in insurance causation jurisprudence. First, the factual allegations about the causal mechanics resulting in the loss can often stretch plausibility as insureds seek coverage and insurers seek to avoid it. Second, over- and under-pleading has made courts wary about what really is the evidence to back up the allegations comprising the causation story in the insurance action. If, for example, an insurer attempts to under-plead the factual connection between the occurrence of the loss and the loss-causing behaviour covered by the insurance policy, how is a court to assess the validity of the interpretation arguments about insurance coverage or lack thereof?

The Supreme Court of Canada in Scalera delineated principles for courts to follow when assessing instances of over or under-pleading in an insurance dispute. The Scalera approach is solely for interpreting descriptive pleading language when determining insurance coverage (or a duty to defend for liability insurance contexts) at the pleadings stage. In Scalera, the insured sought liability insurance coverage for a lawsuit arising out of a sexual assault. The Supreme Court of Canada held that the claim was not covered by the policy and the insurer, therefore, had no duty to defend the alleged perpetrator. ${ }^{81}$ In order to attract insurance coverage and avoid the liability insurance policy's exclusion for "intentional or criminal acts," the victim's pleadings alleged that the perpetrator's loss-causing conduct was negligent. ${ }^{82}$ In actual fact, the conduct was intentional in nature - a sexual assault. The

77 See Knutsen, “Fortuity Clauses,” supra note 1 (liability insurance exclusions are designed to remove coverage for non-fortuitous behaviour which the insured can subjectively control).

See e.g. supra note 60; Murray, supra note 62; Weeks, supra note 62.

And the duty to defend the insured from a lawsuit for legal liability, in addition to indemnity for the loss, for liability insurance. The duty to defend depends on the potential that insurance coverage might possibly be available. See e.g. Monenco Ltd v Commonwealth Insurance Co, 2001 SCC 49, [2001] 2 SCR 699; Nichols v American Home Assurance Co, [1990] 1 SCR 801; Scalera, supra note 17.

80 See Knutsen, "Confusion About Causation,” supra note 11 at 993-94; Ellen S Pryor, “The Stories We Tell: Intentional Harm and the Quest for Insurance Funding” (1997) 75:7 Tex L Rev 1721; Tom Baker, "Constructing the Insurance Relationship: Sales Stories, Claims Stories, and Insurance Contract Damages” (1994) 72:6 Tex L Rev 1395.

81 Scalera, supra note 17 at paras 94, 113, 124

$82 \quad$ Ibid at para 125. 
Court held that, in determining coverage or a duty to defend under an insurance policy at the pleadings stage, courts are not necessarily bound by the "legal labels" for conduct contained in the pleadings. ${ }^{83}$ A court must instead look to the substance and true nature of the allegations being plead. It must evaluate the facts as plead and determine if any of the allegations which sound in negligence are actually "derivative” of an intentional tort (conduct typically excluded by insurance, which insures fortuitous losses only). If so, the negligence labels are "subsumed" into the intentional tort conduct and the intentional tort conduct controls the coverage analysis. ${ }^{84}$ The process is thus designed to hone in on the proper legal descriptor of the actual behaviour being alleged so a proper coverage determination can follow.

For conduct to be deemed "derivative" of some other conduct, it must constitute an "ostensibly separate claim which nonetheless is clearly inseparable" 85 from any other claim. In Scalera, the quality of the alleged sexual assault could not be both negligent and intentional at the same time - sexual assault is always intentional conduct. It is not possible to separate out the negligent conduct from the intentional conduct and still have a stand-alone claim for each. The Court's method is, therefore, designed to solve instances where it is incongruous in law to refer to the same conduct using two very different and exclusive legal descriptors, because the effect of the descriptors bears out very different insurance coverage results. In Scalera, the conduct was deemed intentional for the purposes of the pleadings stage and for determining the insurer's duty to defend. The Scalera approach to over- or under-pleading addresses whether or not the litigant used the legally tenable descriptor for the conduct described in the pleading. Derivative conduct which is "subsumed" into other conduct merely means that one legal label trumps the other for insurance coverage purposes at the pleadings stage.

The Scalera approach is reserved only for assessing appropriateness of the legal labels in pleadings. Unfortunately, as mentioned, courts can conflagrate the terminology and doctrine in the Scalera approach with the process for isolating sufficient target concurrent causes in a concurrent causation liability insurance coverage analysis, a process that takes place after the legal labels in the pleadings are sorted out. Courts can confuse the Scalera approach with doctrines of tort causation and remoteness, as the words "derivative" and "subsumed" prompt courts to evaluate causal mechanics with tort tools. ${ }^{86}$ After the pleadings labels are sorted out,

$83 \quad$ Ibid at para 50.

$84 \quad$ Ibid at para 130 .

85 Ibid at para 85; Durham District, supra note 62 (parents' negligent supervision was held to be a separate negligent act from the child's intentional act of setting a fire); Tedford v TD Insurance Meloche Monnex, 2012 ONCA 429, 112 OR (3d) 144 (there is no derivative conduct when there is only one cause of action - negligent misrepresentation; this was plead, even though different heads of damages were claimed under that cause); Unger, supra note 60 at paras 16-27 (the allegations did not create separate negligent acts from negligent driving); Pizza Pizza, supra note 60 (allegations of negligent business practices did not create a separate tort from a pizza delivery person's negligent driving); McLean, supra note 60 (failure to provide the instructions for snowmobile use was not separable from negligent snowmobile use); TR Construction, supra note 5 (negligent snowmobile maintenance was not separable from allegations of negligent snowmobile use); V-Twin, supra note 60 (negligence in setting up a motorcycle training course was not separate from negligent motorcycle use); Sommerfield, supra note 60 (negligence in failing to report abuse and act of sexual battery were distinct causes of action capable of supporting separate lawsuits); Thompson, supra note 62 (a claim for negligent supervision was not separate from sexual battery in a claim against a correctional facility employee who allegedly abused an inmate). See also the negligent supervision cases, supra note 62. 
the question to answer when evaluating the sufficiency of potential concurrent causes for insurance coverage purposes is this: are the alleged concurrent causes that have been involved in a loss each independently supportable as stand-alone lawsuits such that that each can be necessarily involved in bringing about the end result total loss? This analysis can often look like the Scalera approach to pleadings in operation, but it is assessing the actual legal effect of concurrency of the relevant causes for insurance coverage purposes. It is not assessing the legal labels lawyers gave to the causes. It is thus not correct to conclude, for example, in an automobile accident case that, because an automobile struck a victim, all other allegations of negligence of the insured must, therefore, be "derivative" or "subsumed" into the automobile use because that auto was the instrument of harm. ${ }^{87}$ This is mixing up the Scalera approach to pleadings with the concurrent causation coverage determination.

\section{CONCLUSION}

In conclusion, most coverage and loss distribution disputes which turn on causation can be solved by the following structured process:

1. Remember that the causation inquiry is only designed to determine whether a certain causal mechanic becomes a payout trigger. Avoid inappropriate analogies to tort causation.

2. Isolate the end result loss being claimed. In property insurance contexts, it is the result of the external force on the property itself. In liability insurance, it is the result of the tortious behaviour - the property damage or injury for which legal liability is visited upon the insured.

3. Use the insurance policy to determine potentially relevant causes in the causal mechanics of the loss. Determine whether or not the occurrence which led to the end result loss is covered by the policy in question. If covered, locate the potential causes at play in any applicable exclusions.

4. To determine the causal relevance of a cause, evaluate its temporal and sufficiency dimensions. Determine its timing in its involvement with bringing about the end result loss claimed under the policy. Determine whether or not the cause is necessarily involved in bringing about the end result loss claimed. One cause should present more compelling reasons than others for driving the coverage determination.

5. Verify the result by examining the purposes behind the coverage and exclusion clauses at issue and determining the commercial efficacy of the result on a systemic level.

If a loss may arise from concurrent causes: 
1. To identify if a loss results from concurrent causes in a liability insurance context, each purported cause must be a stand-alone legal claim in order to be a sufficient cause necessarily involved in bringing about the end result loss.

2. To identify if a loss results from concurrent causes in a property insurance context, evaluate the temporal dimension of the purported causes to determine if they are serial or parallel in nature. Then evaluate the sufficiency dimension of the cause to determine if it is necessarily involved in bringing about some of the property damage.

3. To determine coverage, follow the Derksen liberal approach. If one cause in the relevant causal chain of events is covered, the loss is covered even though other non-covered or excluded causes may have also acted concurrently to produce the loss.

4. To determine indemnity, losses resulting from reciprocal concurrent causes in a liability insurance context should be shared equally among insurers. Losses resulting from discrete concurrent causes in a property insurance context should be apportioned based on each cause's role in relation to the total end result dollar value of the damage claimed.

5. Recall that the Scalera approach is reserved for evaluating pleadings language at the pleadings stage only. Insurance coverage determinations are sorted out after the legal labels in the pleadings are set.

The final interpretive exercise in solving coverage or loss distribution disputes turning on insurance causation always rests on an evaluation of the insurance policy language at issue. Here, courts need to take a purposive approach to that language and ask why that language is used. The purpose of the policy, the underwriting intent behind the language used, and the consequences of coverage and coverage gaps on a systemic level all need to be considered. Otherwise, insurance jurisprudence about causation risks continuing to be an unpredictable patchwork that lacks holistic coherence. 